\title{
Modest alcohol consumption and risk of advanced liver fibrosis in nonalcoholic fatty liver disease: a systematic review and meta-analysis
}

\author{
Karn Wijarnpreechaa ${ }^{a}$, Elizabeth S. Aby ${ }^{b}$, Panadeekarn Panjawatananc, Kamolyut Lapumnuaypold, \\ Wisit Cheungpasitporne, Frank J. Lukens ${ }^{b}$, Denise M. Harnois ${ }^{a}$, Patompong Ungprasert ${ }^{f}$ \\ Mayo Clinic, Jacksonville, Florida, USA; University of California at Los Angeles, CA, USA; Chiang Mai University, \\ Chiang Mai, Thailand; Albert Einstein Medical Center, Philadelphia, PA, USA; University of Mississippi Medical \\ Center, Jackson, USA; Siriraj Hospital, Mahidol University, Bangkok, Thailand
}

Abstract

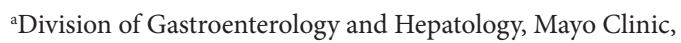
Jacksonville, Florida, USA (Karn Wijarnpreecha, Denise M. Harnois);

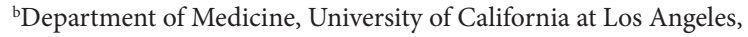
CA, USA (Elizabeth S. Aby, Frank J. Lukens); 'Department of Biochemistry, Faculty of Medicine, Chiang Mai University, Chiang Mai, Thailand (Panadeekarn Panjawatanan); ${ }^{\mathrm{d}}$ Department of Medicine, Albert Einstein Medical Center, Philadelphia, PA, USA (Kamolyut Lapumnuaypol); ${ }^{\mathrm{e}}$ Department of Medicine, Division of Nephrology, University of Mississippi Medical Center, Jackson, USA (Wisit Cheungpasitporn); ${ }^{\mathrm{f}}$ Clinical Epidemiology Unit, Department of Research and Development, Faculty of Medicine, Siriraj Hospital, Mahidol University, Bangkok, Thailand (Patompong Ungprasert)

Conflict of Interest: None

Correspondence to: Karn Wijarnpreecha, MD, 4500 San Pablo Rd S, Jacksonville, 32224 Florida, USA, e-mail: dr.karn.wi@gmail.com

Received 18 August 2020; accepted 30 December 2020; published online 26 February 2021

DOI: https://doi.org/10.20524/aog.2021.0612

\section{Introduction}

Nonalcoholic fatty liver disease (NAFLD) is one of the most common chronic liver diseases worldwide. Its estimated global prevalence is approximately $25-30 \%$ with the highest prevalence observed in the Middle East and South America [1]. Since stage of liver fibrosis is the strongest predictor for mortality in patients with NAFLD [2], interventions that can reduce the degree of liver fibrosis may also decrease mortality rate. However, there are still no medications approved for the treatment of liver fibrosis in NAFLD [3]. Few anti-fibrotic agents, such as simtuzumab and GR-MD-02, are being investigated and are currently in phase II clinical trials [4].

According to the current American Association for the Study of Liver Diseases guidance, the diagnosis of NAFLD indicates a lack of significant alcohol consumption, defined as more than $42 \mathrm{~g}$ of pure alcohol per day in men and more 
than $28 \mathrm{~g}$ of pure alcohol per day in women [3]. Significant alcohol consumption is a well-established risk factor for cirrhosis while modest alcohol consumption is not associated with a significantly increased risk of cirrhosis [5]. The effect of modest alcohol consumption on NAFLD is debatable as studies that investigated the association between modest alcohol consumption and the risk of advanced liver fibrosis have yielded inconsistent results [6-12]. This systematic review and meta-analysis was conducted to better characterize this association by comparing the prevalence of advanced liver fibrosis among NAFLD patients who were modest drinkers to NAFLD patients who were non-drinkers.

\section{Materials and methods}

\section{Data sources and search strategy}

We systematically searched and reviewed literature in MEDLINE and EMBASE databases starting from inception through February 2019 to identify original studies that compared the prevalence of advanced liver fibrosis between patients with NAFLD who were modest drinkers and patients with NAFLD who were non-drinkers. The search algorithms included the terms for "nonalcoholic fatty liver disease", "steatohepatitis", "alcohol consumption", "alcoholism" and "ethanol ingestion" as described in the Online Supplementary Data 1. Three authors (K.W., P.P., and P.U.) independently reviewed the titles and abstracts of the studies resulting from the search. No restrictions were applied in the systematic review. The reference lists in the full text of selected articles were reviewed to identify further relevant studies. This systematic review and meta-analysis was conducted in accordance with the PRISMA (Preferred Reporting Items for Systematic Reviews and Meta-Analysis) statement as demonstrated in the Online Supplementary Data 2.

\section{Selection criteria}

The eligible studies included were required to be crosssectional studies of patients with NAFLD that compared the prevalence of advanced liver fibrosis among patients with NAFLD who were modest drinkers (generally defined as less than $28 \mathrm{~g}$ per day in men and less than $14 \mathrm{~g}$ per day in women although some variations were allowed) [13] to the prevalence of advanced liver fibrosis among patients with NAFLD who were non-drinkers. The eligible studies were required to provide odds ratio (OR) and 95\% confidence interval (CI) for this comparison or enough raw data to calculate these data. We considered all articles irrespective of the study size or type of article, such as short reports or conference abstracts. In the case of multiple studies utilizing the same population or database, the most recent study or more comprehensive data set was included.

Three authors (K.W., P.P., and P.U.) independently reviewed the eligible studies; discrepancies were discussed and agreement was reached by the consensus. The modified Newcastle-Ottawa quality assessment scale was used to appraise the quality of the cross-sectional studies in 3 domains, including selection of the sample, comparability between the groups, and assessment of the outcomes [14].

\section{Data abstraction}

The following data were extracted from each study: the citation data, the title of the study, the first author's last name, the publication year, the study design, the country where the study was conducted, the characteristics of the population, the number of the participants, methods used to quantify alcohol consumption, the definition of modest alcohol consumption, methods used to diagnose NAFLD, the methods used to diagnose advanced liver fibrosis, the adjusted effect estimates with 95\%CI, and the confounding factors adjusted for in the multivariable analysis.

To ensure the accuracy, this data extraction process was independently performed by 2 investigators (K.W. and P.P.) and was reviewed by the senior investigator (P.U.).

\section{Statistical analysis}

For the statistical analysis, we used the Cochrane Collaboration's Review Manager 5.3 software (London, United Kingdom). A P-value lower than 0.05 indicates statistical significance (except for the heterogeneity). Adjusted point estimates from each study were consolidated by the generic inverse variance method of DerSimonian and Laird, which assigned the weight of each study for the pooled analysis based on its variance [15]. In light of the high probability of high between-study variance because of the different background populations and methods used to diagnose advanced liver fibrosis and definitions of modest alcohol consumption, random-effect model was chosen rather than fix-effect model. We also calculated the Cochran's Q test and $I^{2}$ statistic to quantify the percentage variation across the included studies due to heterogeneity. We used an $I^{2}$ cut-off of $\leq 25 \%, 26 \%-50 \%$, $51 \%-75 \%$, and $>75 \%$ to represent insignificant, low, moderate and high heterogeneity, respectively [16]. We used funnel plot to assess for the presence of publication bias.

\section{Results}

A total of 10,510 potentially eligible articles were identified using the described search strategy (3,957 from MEDLINE and 6,553 from EMBASE). After exclusion of 3,134 duplicate articles, the abstracts of 7,376 unique articles were reviewed. Seven thousand three-hundred and thirty-six manuscripts were then excluded given they were case reports, case series, correspondence items, review articles, in vitro studies, animal studies, or interventional studies. Forty articles met criteria for full-text review; however, 28 articles were excluded because they 
did not report the outcome of interest and 5 articles were excluded because they were descriptive studies without comparative analysis. A total of 7 studies fulfilled the eligibility criteria [6-12]. However, one article was excluded since it used NAFLD fibrosis score of more than -1.455 as a cut off for advanced fibrosis [12]. We considered this cut-off to be inappropriate as it included both patients with intermediate and high probability of advanced fibrosis, instead of just high probability of advanced fibrosis. The final meta-analysis included 6 studies [6-11] with 8,936 participants. The literature retrieval, review, and selection process are shown in Fig. 1. The characteristics and quality appraisal of the included studies are presented in Table 1.

\section{Association between modest alcohol consumption and advanced liver fibrosis in NAFLD}

The prevalence of advanced liver fibrosis among NAFLD patients who were modest drinkers was significantly lower than NAFLD patients who were non-drinkers with the pooled OR of 0.51 (95\%CI $0.35-0.75)$. The between-study heterogeneity was low with an $I^{2}$ of $47 \%$. The forest plot is shown in Fig. 2.

\section{Sensitivity analysis}

Two sensitivity analyses were conducted. The first sensitivity analysis was conducted by including only studies that used histopathology to determine advanced liver fibrosis as histopathology is considered the gold-standard. A total of 4 studies were included $[6-8,11]$. The prevalence of advanced liver fibrosis among NAFLD patients who were modest drinkers was significantly lower than NAFLD patients who were non-drinkers with the pooled OR of 0.49 (95\%CI 0.36$0.66)$. The between-study heterogeneity was negligible with an $I^{2}$ of $0 \%$.

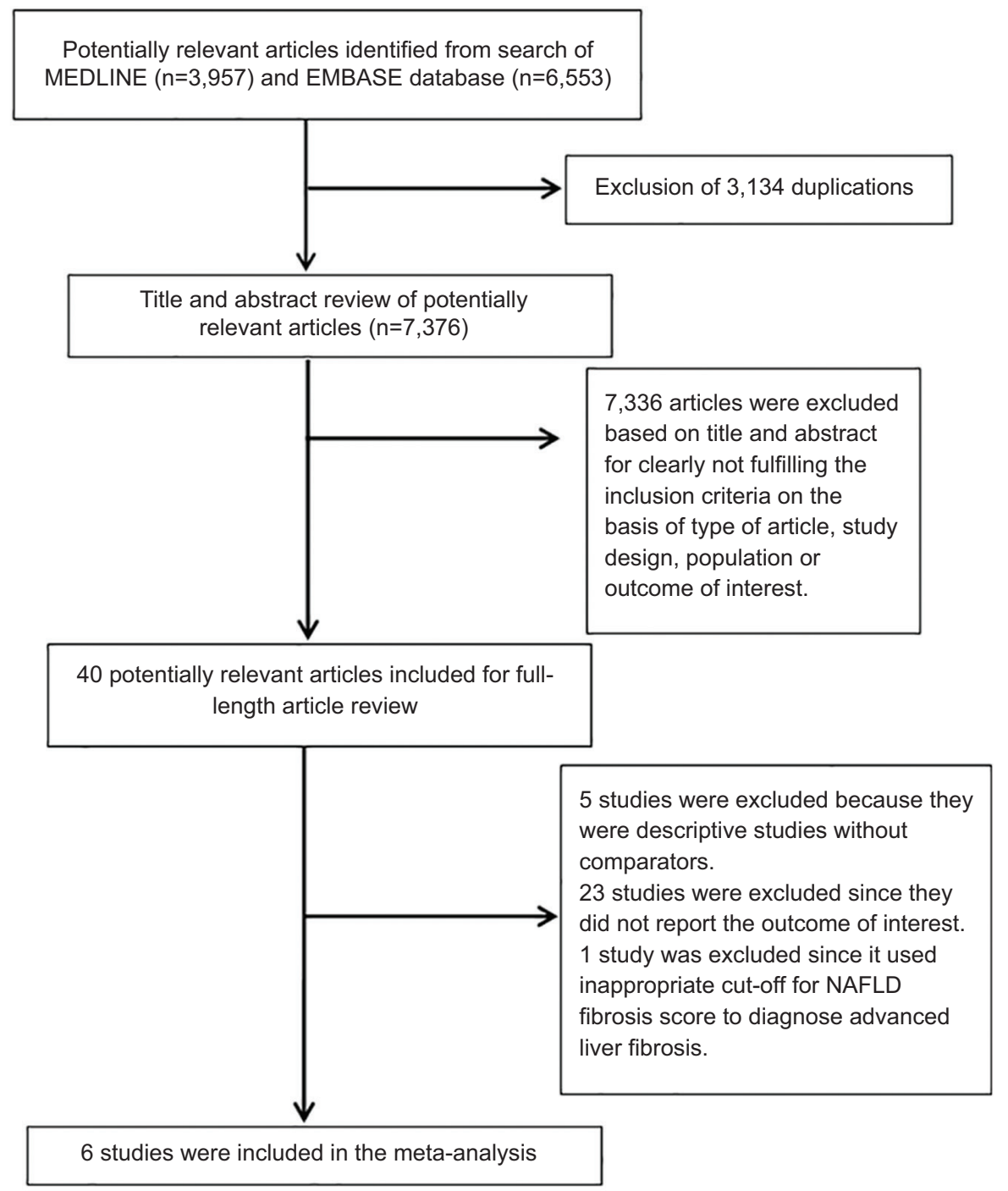

Figure 1 Literature review process NAFLD, nonalcoholic fatty liver disease 


\begin{tabular}{|c|c|c|c|c|c|c|c|c|c|}
\hline Study or Subgroup & log[Odds Ratio] & SE & Weight & $\begin{array}{c}\text { Odds Ratio } \\
\text { IV, Random, } 95 \% \mathrm{CI}\end{array}$ & Year & & $\begin{array}{l}\text { Odds } \\
\text { IV, Randor }\end{array}$ & $\begin{array}{l}\text { Ratio } \\
\mathrm{m}, 95 \% \mathrm{Cl}\end{array}$ & \\
\hline Dunn et al & -0.6232 & 0.1905 & $28.0 \%$ & $0.54[0.37,0.78]$ & 2012 & & -- & & \\
\hline Kwon et al & -1.1294 & 0.5669 & $9.1 \%$ & $0.32[0.11,0.98]$ & 2013 & & & & \\
\hline Patel et al & 0.5822 & 0.5014 & $10.9 \%$ & $1.79[0.67,4.78]$ & 2017 & & - & & \\
\hline Yamada et al & -0.5345 & 0.3799 & $15.7 \%$ & $0.59[0.28,1.23]$ & 2018 & & 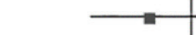 & . & \\
\hline Mitchell et al & -1.1087 & 0.4023 & $14.7 \%$ & $0.33[0.15,0.73]$ & 2018 & & - & & \\
\hline Unalp-Arida et al & -0.9676 & 0.2789 & $21.5 \%$ & $0.38[0.22,0.66]$ & 2018 & & $\longrightarrow$ & & \\
\hline Tatal $(95 \% \mathrm{Cl})$ & & & $100.0 \%$ & $0.51[0.35,0.75]$ & & & & & \\
\hline \multicolumn{6}{|c|}{$\begin{array}{l}\text { Heterogeneity: } \mathrm{Tau}^{2}=0.10 ; \mathrm{Chi}^{2}=9.40, \mathrm{df}=5(\mathrm{P}=0.09) ; \mathrm{I}^{2}-47 \% \\
\text { Test for overall effect: } Z=3.41(\mathrm{P}=0.0007)\end{array}$} & 0.05 & $\begin{array}{c}0.2 \\
\text { Alc lessfibrosis }\end{array}$ & 1 Alc more fibrosis & 20 \\
\hline
\end{tabular}

Figure 2 Forest plot of all studies

SE, standard error; CI, confidence interval

Table 1 Main characteristics of the studies included in this meta-analysis

\begin{tabular}{|c|c|c|c|}
\hline Study & Dunn et al [6] & Kwon et al [7] & Patel et al [9] \\
\hline Country & United States & United States & Australia \\
\hline Study design & Cross-sectional study & Cross-sectional study & Cross-sectional study \\
\hline Year & 2012 & 2013 & 2017 \\
\hline $\begin{array}{l}\text { Total number of } \\
\text { participants }\end{array}$ & $\begin{array}{l}583 \text { ( } 331 \text { modest alcohol drinkers } \\
\text { and } 252 \text { non-drinkers) }\end{array}$ & $\begin{array}{l}77 \text { ( } 52 \text { modest alcohol drinkers and } \\
25 \text { non-drinkers) }\end{array}$ & $\begin{array}{l}116 \text { ( } 70 \text { modest alcohol drinkers and } 46 \\
\text { non-drinkers) }\end{array}$ \\
\hline Study participants & $\begin{array}{l}\text { Participants were patients with } \\
\text { NAFLD aged } \geq 21 \text { years enrolled } \\
\text { in one of the } 2 \text { NASH CRN studies } \\
\text { (the NAFLD Database and the } \\
\text { PIVENS study). Only patients } \\
\text { who underwent liver biopsy were } \\
\text { included }\end{array}$ & $\begin{array}{l}\text { Participants were patients with } \\
\text { histologically-confirmed NAFLD } \\
\text { recruited from the hepatology clinic } \\
\text { of the University of Michigan from } \\
\text { March } 2003 \text { to November } 2004\end{array}$ & $\begin{array}{l}\text { Participants were patients with NAFLD } \\
\text { who also had T2DM. They were recruited } \\
\text { from the endocrine clinic of the Princess } \\
\text { Alexandra Hospital, Brisbane, Australia and } \\
\text { primary care practices within the Metro } \\
\text { South Hospital and Health Services Districts } \\
\text { from October } 2015 \text { to November } 2016\end{array}$ \\
\hline $\begin{array}{l}\text { Definition of modest } \\
\text { alcohol consumption }\end{array}$ & $\begin{array}{l}\text { History of alcohol consumption was } \\
\text { obtained from questionnaire. } \\
\text { Modest drinkers were defined as } \\
\text { currently drinking with average } \\
\text { alcohol consumption of }<20 \mathrm{~g} \text { daily } \\
\text { during the } 2 \text { years before entry }\end{array}$ & $\begin{array}{l}\text { History of alcohol consumption was } \\
\text { obtained from direct interview. } \\
\text { Modest drinkers were defined as } \\
\text { currently drinking with average } \\
\text { alcohol consumption of }<24 \text { g-years }\end{array}$ & $\begin{array}{l}\text { History of alcohol consumption was } \\
\text { obtained from questionnaire. } \\
\text { Modest drinkers were defined as } \\
\text { currently drinking with average alcohol } \\
\text { consumption } \leq 20 \text { g daily and never drink } \\
\text { alcohol }>20 \text { g per day }\end{array}$ \\
\hline Diagnosis of NAFLD & $\begin{array}{l}\text { NAFLD Database: Diagnosis of } \\
\text { NAFLD required histology plus } \\
\text { imaging suggestive of NAFLD } \\
\text { without any other causes of liver } \\
\text { disease and significant alcohol } \\
\text { consumption (average alcohol } \\
\text { consumption }>20 \text { daily during the } \\
2 \text { years before entry). } \\
\text { PIVENS study: Criteria for diagnosis } \\
\text { were similar to NAFLD Database } \\
\text { plus histological evidence of NASH } \\
\text { without cirrhosis and diabetes }\end{array}$ & $\begin{array}{l}\text { Diagnosis of NAFLD required } \\
\text { histology without any other causes of } \\
\text { liver disease and significant alcohol } \\
\text { consumption ( }>40 \text { g per week) }\end{array}$ & $\begin{array}{l}\text { NAFLD was diagnosed based on the } \\
\text { presence of fatty liver on US without any } \\
\text { other causes of liver disease and significant } \\
\text { alcohol consumption ( }>20 \text { g per day) }\end{array}$ \\
\hline $\begin{array}{l}\text { Definition of advanced } \\
\text { liver fibrosis }\end{array}$ & $\begin{array}{l}\text { Advanced fibrosis was defined by } \\
\text { histopathology showing fibrosis } \\
\text { stage 3-4 }\end{array}$ & $\begin{array}{l}\text { Advanced fibrosis was defined by } \\
\text { histopathology showing fibrosis } \\
\text { stage 3-4 }\end{array}$ & $\begin{array}{l}\text { Advanced fibrosis was defined as liver } \\
\text { stiffness of }>8.2 \mathrm{kPa} \text { from transient } \\
\text { elastography }\end{array}$ \\
\hline $\begin{array}{l}\text { Confounder adjusted in } \\
\text { multivariate analysis }\end{array}$ & None & None & Age, sex and BMI \\
\hline $\begin{array}{l}\text { Quality assessment } \\
\text { (Newcastle-Ottawa } \\
\text { scale) }\end{array}$ & $\begin{array}{l}\text { Selection: } 4 \\
\text { Comparability: } 1 \\
\text { Outcome: } 3\end{array}$ & $\begin{array}{l}\text { Selection: } 4 \\
\text { Comparability: } 1 \\
\text { Outcome: } 3\end{array}$ & $\begin{array}{l}\text { Selection: } 3 \\
\text { Comparability: } 2 \\
\text { Outcome: } 3\end{array}$ \\
\hline
\end{tabular}

NAFLD, nonalcoholic fatty liver disease; IHTG, intrahepatic triglyceride; H-MRS, proton-magnetic resonance spectroscopy; NASH, nonalcoholic steatohepatitis; CRN, Clinical Research Network; Peth, phosphatidyl ethanol; NAS, nonalcoholic fatty liver disease activity score; SAF, steatosis activity fibrosis; FLIP, fatty liver inhibition of progression; DM, diabetes mellitus; HTN, hypertension; BMI, body mass index; US, ultrasonography; FIB-4, fibrosis-4 


\begin{tabular}{|c|c|c|c|}
\hline Study & Mitchell et al [8] & Unalp-Arida et al [10] & Yamada et al [11] \\
\hline Country & Australia & United States & Japan \\
\hline Study design & Cross-sectional study & Cross-sectional study & Cross-sectional study \\
\hline Year & 2018 & 2018 & 2018 \\
\hline Total number & $\begin{array}{l}146 \text { ( } 72 \text { modest alcohol drinkers } \\
\text { and } 74 \text { non-drinkers) }\end{array}$ & $\begin{array}{l}\text { 7,836 (4,879 modest alcohol drinkers } \\
\text { and 2,957 non-drinkers) }\end{array}$ & $\begin{array}{l}178 \text { ( } 77 \text { modest alcohol drinkers } \\
\text { and } 101 \text { non-drinkers) }\end{array}$ \\
\hline Study participants & $\begin{array}{l}\text { Participants were patients with } \\
\text { histologically-confirmed NAFLD } \\
\text { recruited from the hepatology } \\
\text { clinic or bariatric surgery clinic of } \\
\text { the Sir Charles Gairdner Hospital, } \\
\text { Australia }\end{array}$ & $\begin{array}{l}\text { Participants were patients with } \\
\text { NAFLD identified from the cohort of } \\
\text { HCHS/SOL from 2008-2011 }\end{array}$ & $\begin{array}{l}\text { Participants were patients with } \\
\text { histologically-confirmed NAFLD } \\
\text { recruited from the Graduate } \\
\text { School of Medicine of the } \\
\text { Kanazawa University Hospital, } \\
\text { Japan, from 1998-2013 }\end{array}$ \\
\hline $\begin{array}{l}\text { Definition of modest } \\
\text { alcohol consumption }\end{array}$ & $\begin{array}{l}\text { History of alcohol consumption } \\
\text { was obtained from questionnaire } \\
\text { plus direct interview. } \\
\text { Modest drinkers were defined as } \\
\text { currently drinking with average } \\
\text { alcohol consumption of }<70 \text { g per } \\
\text { week }\end{array}$ & $\begin{array}{l}\text { History of alcohol consumption was } \\
\text { obtained from questionnaire. } \\
\text { Modest drinkers were defined as } \\
\text { currently drinking with average } \\
\text { alcohol consumption of 1-14 drinks/ } \\
\text { week in females and 1-21 drinks/week } \\
\text { in males }\end{array}$ & $\begin{array}{l}\text { History of alcohol consumption } \\
\text { was obtained from direct } \\
\text { interview. } \\
\text { Modest drinkers were defined as } \\
\text { currently drinking with average } \\
\text { alcohol consumption of } \\
\leq 20 \mathrm{~g} / \text { day }\end{array}$ \\
\hline Diagnosis of NAFLD & $\begin{array}{l}\text { Diagnosis of NAFLD required } \\
\text { histology without any other causes } \\
\text { of liver disease and significant } \\
\text { alcohol consumption ( }>21 \text { drinks } \\
\text { per week for males and }>14 \text { drinks } \\
\text { per week for females) }\end{array}$ & $\begin{array}{l}\text { NAFLD was diagnosed based on the } \\
\text { presence of fatty liver on magnetic } \\
\text { resonance spectroscopy (liver fat } \\
\text { score } \geq 1.257 \text { ) without any other } \\
\text { causes of liver disease and significant } \\
\text { alcohol consumption ( }>14 \text { drinks/ } \\
\text { week in females and }>21 \text { drinks/week } \\
\text { in males) }\end{array}$ & $\begin{array}{l}\text { Diagnosis of NAFLD required } \\
\text { histology without any other } \\
\text { causes of liver disease and } \\
\text { significant alcohol consumption } \\
\text { ( }>21 \text { g per day) }\end{array}$ \\
\hline $\begin{array}{l}\text { Definition of advanced } \\
\text { liver fibrosis }\end{array}$ & $\begin{array}{l}\text { Advanced fibrosis was defined by } \\
\text { histopathology showing fibrosis } \\
\text { stage } 3-4\end{array}$ & $\begin{array}{l}\text { Advanced fibrosis was defined by } \\
\text { NAFLD fibrosis score of }>0.676\end{array}$ & $\begin{array}{l}\text { Advanced fibrosis was defined by } \\
\text { histopathology showing fibrosis } \\
\text { stage 3-4 }\end{array}$ \\
\hline $\begin{array}{l}\text { Confounder adjusted in } \\
\text { multivariate analysis }\end{array}$ & Age, BMI and DM & $\begin{array}{l}\text { Age, sex, heritage group, education, } \\
\text { BMI and physical activity }\end{array}$ & None \\
\hline $\begin{array}{l}\text { Quality assessment } \\
\text { (Newcastle-Ottawa scale) }\end{array}$ & $\begin{array}{l}\text { Selection: } 4 \\
\text { Comparability: } 2 \\
\text { Outcome: } 3\end{array}$ & $\begin{array}{l}\text { Selection: } 5 \\
\text { Comparability: } 2 \\
\text { Outcome: } 3\end{array}$ & $\begin{array}{l}\text { Selection: } 4 \\
\text { Comparability: } 1 \\
\text { Outcome: } 3\end{array}$ \\
\hline
\end{tabular}

NAFLD, nonalcoholic fatty liver disease; NASH, nonalcoholic steatohepatitis; CRN, Clinical Research Network; BMI, body mass index; DM, diabetes mellitus; HCHS/SOL, Hispanic Community Health Study/Study of Latinos; US, ultrasonography

The second sensitivity analysis was conducted by excluding the study published as conference abstract and does not undergo peer-review yet [10]. Exclusion of this study did not significantly alter the pooled result as the prevalence of advanced liver fibrosis among NAFLD patients who were modest drinkers was still significantly lower than NAFLD patients who were non-drinkers with the pooled OR of 0.56 ( $95 \%$ CI $0.35-0.89)$. The between-study heterogeneity was low with an $I^{2}$ of $50 \%$.

\section{Evaluation for publication bias}

A funnel plot was constructed based on the effect estimate and accuracy of each study to assess for the presence of publication bias (Fig. 3). The funnel plot was symmetric and not suggestive of publication bias.

\section{Discussion}

The current study is the first systematic review and metaanalysis that summarizes all available studies on the association between modest alcohol consumption and risk of advanced liver fibrosis among patients with NAFLD. Interestingly, we found that modest alcohol consumption is inversely associated with advanced liver fibrosis among patients with NAFLD. The reasons for this suggested protective effect of modest alcohol consumption on presence of advanced fibrosis are not known [17]. It seems contradictory that alcohol consumption may provide a beneficial effect to the liver when excessive alcohol consumption is a wellestablished cause of chronic liver disease [18].

There are many possible explanations for why modest alcohol disease may be protective. The first explanation is related to insulin resistance. Studies have demonstrated that moderate alcohol consumption is associated with increased peripheral insulin sensitivity, decreased basal insulin secretion 


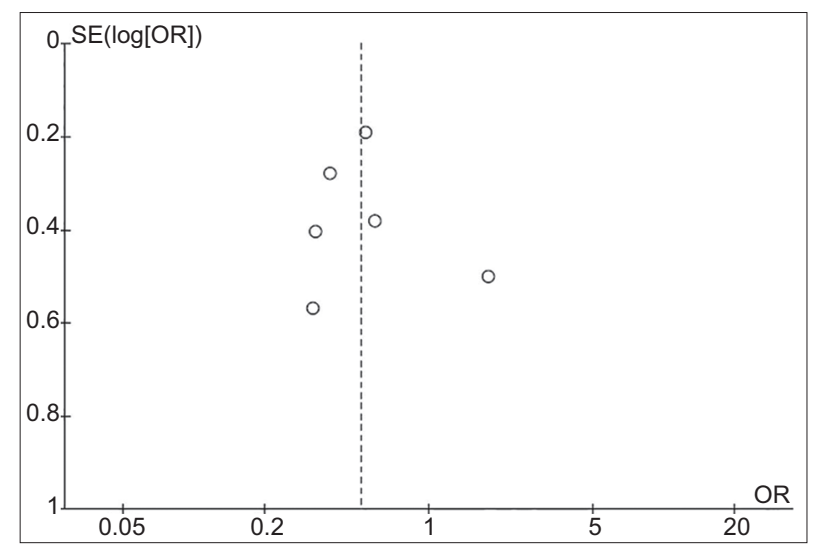

Figure 3 Funnel plot of all studies OR, odds ratio

rate, and lower fasting plasma glucagon concentrations in healthy subjects $[19,20]$. In fact, several epidemiological studies have demonstrated a significantly lower risk of incident diabetes mellitus among moderate drinkers [21,22]. Since insulin resistance plays an important role in the development of hepatic steatosis, modest alcohol consumption may help slow down this process and thus, lower the chance of progression to liver fibrosis.

The second possible mechanism is related to adiponectin, a hormone that regulates hepatic stellate cells (HSC). Adiponectin inhibits proliferation and migration of HSC by decreasing matrix metalloproteinases-1 and increasing the expression of tissue inhibitor of metalloproteinase-1 [23]. Studies have found the increased levels of adiponectin among alcohol drinkers $[24,25]$, which may reduce HSC proliferation and migration, the essential steps in the development of liver fibrosis [23].

Antioxidants found in wine may also play a protective role against inflammation and subsequent fibrosis [26-28]. Red wine has been shown to have a greater anti-inflammatory effect when compared to white wine, thought to be due to higher polyphenol content [29]. In addition, work by Yamada et al suggests that modest alcohol consumption may suppress the activity of nonalcoholic steatohepatitis by reducing the expression of genes involved in immune response [11].

On the other hand, this association may not be causal. It is possible that NAFLD patients with advanced liver fibrosis (F3) or cirrhosis (F4) may have been strongly encouraged by their physicians to quit alcohol completely and, thus, a higher prevalence of non-drinkers among those with advanced liver fibrosis/cirrhosis.

Although the quality of included studies was high, as reflected by the high Newcastle-Ottawa scores, and the literature identification process was comprehensive, this meta-analysis has some limitations and therefore, the results should be interpreted with caution. First, most of the included studies only minimally adjusted their results for potential confounders and several important confounders, such as sex, body mass index, diabetes, smoking, and comorbid conditions, were not appropriately adjusted for. Therefore, it is possible that confounders associated with alcohol consumption and behavior, not the modest alcohol consumption itself, were responsible for this apparent protective effect. Second, statistical heterogeneity was not low in the meta-analysis. We believe that the differences in study populations and methodologies were the main sources of the between-study variation. Third, almost all of the included studies were conducted in Western countries. Studies have shown that there are significant racial and ethnic disparities in NAFLD prevalence and severity [30-32]. Therefore, the generalizability of the results to other populations may be limited. Another limitation is that many of these studies have defined modest alcohol consumption without taking into account different thresholds for women vs. men.

In conclusion, this study demonstrated a significant association between modest alcohol consumption and a decreased risk of advanced liver fibrosis among patients with NAFLD. However, further studies are required to determine whether this association is causal or causative.

\section{Summary Box}

\section{What is already known:}

- Heavy alcohol consumption or binge drinking is a risk factor for developing cirrhosis in nonalcoholic fatty liver disease (NAFLD)

- Previous studies showed that modest of alcohol consumption in patients with NAFLD may associated with decreased risk of liver fibrosis; however, the results from those studies varied considerably

\section{What the new findings are:}

- This meta-analysis from 6 cross-sectional studies with 8,936 participants showed that the risk of advanced liver fibrosis among patients with NAFLD was lower than those without modest alcohol consumption

- However, the included studies have defined modest alcohol consumption without taking into account different thresholds for women vs. men

\section{References}

1. Younossi ZM, Koenig AB, Abdelatif D, Fazel Y, Henry L, Wymer M. Global epidemiology of nonalcoholic fatty liver diseaseMeta-analytic assessment of prevalence, incidence, and outcomes. Hepatology 2016;64:73-84.

2. Hagstrom H, Nasr P, Ekstedt M, et al. Fibrosis stage but not NASH predicts mortality and time to development of severe liver disease in biopsy-proven NAFLD. J Hepatol 2017;67:1265-1273.

3. Chalasani N, Younossi Z, Lavine JE, et al. The diagnosis and management of nonalcoholic fatty liver disease: Practice guidance 
from the American Association for the Study of Liver Diseases. Hepatology 2018;67:328-357.

4. Albhaisi S, Sanyal A. Recent advances in understanding and managing non-alcoholic fatty liver disease. F1000Res 2018;7:F1000 Faculty Rev-720.

5. Rehm J, Taylor B, Mohapatra S, et al. Alcohol as a risk factor for liver cirrhosis: a systematic review and meta-analysis. Drug Alcohol Rev 2010;29:437-445.

6. Dunn W, Sanyal AJ, Brunt EM, et al. Modest alcohol consumption is associated with decreased prevalence of steatohepatitis in patients with non-alcoholic fatty liver disease (NAFLD). J Hepatol 2012;57:384-391.

7. Kwon HK, Greenson JK, Conjeevaram HS. Effect of lifetime alcohol consumption on the histological severity of non-alcoholic fatty liver disease. Liver Int 2014;34:129-135.

8. Mitchell T, Jeffrey GP, de Boer B, et al. Type and pattern of alcohol consumption is associated with liver fibrosis in patients with nonalcoholic fatty liver disease. Am J Gastroenterol 2018;113:14841493.

9. Patel PJ, Smith D, Connor JP, et al. Alcohol consumption in diabetic patients with nonalcoholic fatty liver disease. Can J Gastroenterol Hepatol 2017;2017:7927685.

10. Unalp-Arida ARC, Kallwitz E, Daviglus M, et al. Low-moderate alcohol use is associated with a lower prevalence of non-alcoholic fatty liver disease in Hispanics/Latinos living in the US: Results from the Hispanic Community Health Study/Study of Latinos (HCHS/SOL). J Hepatol 2018;68(Suppl 1):S836-S837.

11. Yamada K, Mizukoshi E, Seike T, et al. Light alcohol consumption has the potential to suppress hepatocellular injury and liver fibrosis in non-alcoholic fatty liver disease. PLoS One 2018;13:e0191026.

12. Yu C, Wang L, Xue H, Lin H, Li Y, Chan SO. Association of glycated hemoglobin with the risk of advanced fibrosis in non-alcoholic fatty liver disease patients without diabetes. Clin Res Hepatol Gastroenterol 2019;43:58-66.

13. Alcohol research: current reviews editorial S. drinking patterns and their definitions. Alcohol Res 2018;39:17-18.

14. Herzog R, Alvarez-Pasquin MJ, Diaz C, Del Barrio JL, Estrada JM, Gil A. Are healthcare workers' intentions to vaccinate related to their knowledge, beliefs and attitudes? A systematic review. BMC Public Health 2013;13:154.

15. DerSimonian R, Laird N. Meta-analysis in clinical trials. Control Clin Trials 1986:7:177-188.

16. Higgins JP, Thompson SG, Deeks JJ, Altman DG. Measuring inconsistency in meta-analyses. BMJ 2003;327:557-560.

17. Ajmera VH, Terrault NA, Harrison SA. Is moderate alcohol use in nonalcoholic fatty liver disease good or bad? A critical review. Hepatology 2017;65:2090-2099.

18. You M, Crabb DW. Recent advances in alcoholic liver disease II.
Minireview: molecular mechanisms of alcoholic fatty liver. Am J Physiol Gastrointest Liver Physiol 2004;287:G1-G6.

19. Bonnet F, Disse E, Laville M, et al. Moderate alcohol consumption is associated with improved insulin sensitivity, reduced basal insulin secretion rate and lower fasting glucagon concentration in healthy women. Diabetologia 2012;55:3228-3237.

20. Lazarus R, Sparrow D, Weiss ST. Alcohol intake and insulin levels. The normative aging study. Am J Epidemiol 1997;145:909-916.

21. Baliunas DO, Taylor BJ, Irving H, et al. Alcohol as a risk factor for type 2 diabetes: a systematic review and meta-analysis. Diabetes Care 2009;32:2123-2132.

22. Carlsson S, Hammar N, Grill V, Kaprio J. Alcohol consumption and the incidence of type 2 diabetes: a 20 -year follow-up of the finnish twin cohort study. Diabetes Care 2003;26:2785-2790.

23. Ramezani-Moghadam M, Wang $\mathrm{J}$, Ho V, et al. Adiponectin reduces hepatic stellate cell migration by promoting tissue inhibitor of metalloproteinase-1 (TIMP-1) secretion. J Biol Chem 2015;290:5533-5542.

24. Pischon T, Girman CJ, Rifai N, Hotamisligil GS, Rimm EB. Association between dietary factors and plasma adiponectin concentrations in men. Am J Clin Nutr 2005;81:780-786.

25. Sierksma A, Patel H, Ouchi N, et al. Effect of moderate alcohol consumption on adiponectin, tumor necrosis factor-alpha, and insulin sensitivity. Diabetes Care 2004;27:184-189.

26. Ajmo JM, Liang X, Rogers CQ, Pennock B, You M. Resveratrol alleviates alcoholic fatty liver in mice. Am J Physiol Gastrointest Liver Physiol 2008;295:G833-G842.

27. Becker U, Gronbaek M, Johansen D, Sorensen TI. Lower risk for alcohol-induced cirrhosis in wine drinkers. Hepatology 2002;35:868-875.

28. Dunn $\mathrm{W}, \mathrm{Xu} \mathrm{R}$, Schwimmer JB. Modest wine drinking and decreased prevalence of suspected nonalcoholic fatty liver disease. Hepatology 2008;47:1947-1954.

29. Sacanella E, Vazquez-Agell M, Mena MP, et al. Down-regulation of adhesion molecules and other inflammatory biomarkers after moderate wine consumption in healthy women: a randomized trial. Am J Clin Nutr 2007;86:1463-1469.

30. Rich NE, Oji S, Mufti AR, et al. Racial and ethnic disparities in nonalcoholic fatty liver disease prevalence, severity, and outcomes in the United States: a systematic review and meta-analysis. Clin Gastroenterol Hepatol 2018;16:198-210 e192.

31. Tabibian JH, Lazo M, Durazo FA, Yeh HC, Tong MJ, Clark JM. Nonalcoholic fatty liver disease across ethno-racial groups: do Asian-American adults represent a new at-risk population? $J$ Gastroenterol Hepatol 2011;26:501-509.

32. Weston SR, Leyden W, Murphy R, et al. Racial and ethnic distribution of nonalcoholic fatty liver in persons with newly diagnosed chronic liver disease. Hepatology 2005;41:372-379. 


\section{Supplementary material}

Online Supplementary Data 1 Search Strategy

Database: Ovid MEDLINE

1. Nonalcoholic fatty liver.mp. or exp Nonalcoholic fatty liver disease/

2. fatty liver.mp. or exp fatty liver/

3. nonalcoholic steatohepatitis.mp.

4. steatohepatitis.mp.

5. or/1-4

6. alcohol consumption.mp. or exp Alcohol Drinking/

7. alcoholism.mp. or exp Alcoholism/

8. alcohol abuse.mp.

9. exp Ethanol/ or ethanol ingestion.mp.

10. or/6-9

11.5 and 10

Database: EMBASE

1. 'Nonalcoholic fatty liver' or 'Nonalcoholic fatty liver'/exp

2. 'fatty liver'/exp OR 'fatty liver'

3. 'steatohepatitis'/exp OR 'steatohepatitis'

4. 'nonalcoholic' AND ('steatohepatitis'/exp OR steatohepatitis)

5. or/1-4

6. 'alcohol consumption'/exp OR 'alcohol consumption'

7. 'alcoholism'/exp OR 'alcohoism'

8. 'alcohol abuse'/exp OR 'alcohol abuse'

9. ('ethanol'/exp OR ethanol) AND ('ingestion'/exp OR ingestion)

10. or/6-9

11.5 and 10 
Online Supplementary Data 2 PRISMA checklist

\begin{tabular}{|c|c|c|c|}
\hline Section/topic & \# & Checklist item & Reported on page \# \\
\hline \multicolumn{4}{|l|}{ TITLE } \\
\hline Title & 1 & Identify the report as a systematic review, meta-analysis, or both. & 1 \\
\hline \multicolumn{4}{|l|}{ ABSTRACT } \\
\hline Structured summary & 2 & $\begin{array}{l}\text { Provide a structured summary including, as applicable: background; objectives; data } \\
\text { sources; study eligibility criteria, participants, and interventions; study appraisal and } \\
\text { synthesis methods; results; limitations; conclusions and implications of key findings; } \\
\text { systematic review registration number. }\end{array}$ & 2 \\
\hline \multicolumn{4}{|l|}{ INTRODUCTION } \\
\hline Rationale & 3 & Describe the rationale for the review in the context of what is already known. & 3 \\
\hline Objectives & 4 & $\begin{array}{l}\text { Provide an explicit statement of questions being addressed with reference to } \\
\text { participants, interventions, comparisons, outcomes, and study design (PICOS). }\end{array}$ & 3 \\
\hline \multicolumn{4}{|l|}{ METHODS } \\
\hline Protocol and registration & 5 & $\begin{array}{l}\text { Indicate if a review protocol exists, if and where it can be accessed (e.g., Web address), } \\
\text { and, if available, provide registration information including registration number. }\end{array}$ & $3-4$ \\
\hline Eligibility criteria & 6 & $\begin{array}{l}\text { Specify study characteristics (e.g., PICOS, length of follow-up) and report } \\
\text { characteristics (e.g., years considered, language, publication status) used as criteria for } \\
\text { eligibility, giving rationale. }\end{array}$ & 4 \\
\hline Information sources & 7 & $\begin{array}{l}\text { Describe all information sources (e.g., databases with dates of coverage, contact with } \\
\text { study authors to identify additional studies) in the search and date last searched. }\end{array}$ & 4 \\
\hline Search & 8 & $\begin{array}{l}\text { Present full electronic search strategy for at least one database, including any limits } \\
\text { used, such that it could be repeated. }\end{array}$ & $3-4$ \\
\hline Study selection & 9 & $\begin{array}{l}\text { State the process for selecting studies (i.e., screening, eligibility, included in systematic } \\
\text { review, and, if applicable, included in the meta-analysis). }\end{array}$ & $4-5$ \\
\hline Data collection process & 10 & $\begin{array}{l}\text { Describe method of data extraction from reports (e.g., piloted forms, independently, in } \\
\text { duplicate) and any processes for obtaining and confirming data from investigators. }\end{array}$ & 5 \\
\hline Data items & 11 & $\begin{array}{l}\text { List and define all variables for which data were sought (e.g., PICOS, funding sources) } \\
\text { and any assumptions and simplifications made. }\end{array}$ & 5 \\
\hline $\begin{array}{l}\text { Risk of bias in individual } \\
\text { studies }\end{array}$ & 12 & $\begin{array}{l}\text { Describe methods used for assessing risk of bias of individual studies (including } \\
\text { specification of whether this was done at the study or outcome level), and how this } \\
\text { information is to be used in any data synthesis. }\end{array}$ & Table 1 \\
\hline Summary measures & 13 & State the principal summary measures (e.g., risk ratio, difference in means). & 5 \\
\hline Synthesis of results & 14 & $\begin{array}{l}\text { Describe the methods of handling data and combining results of studies, if done, } \\
\left.\text { including measures of consistency (e.g., } \mathrm{I}^{2}\right) \text { for each meta-analysis. }\end{array}$ & 5 \\
\hline Risk of bias across studies & 15 & $\begin{array}{l}\text { Specify any assessment of risk of bias that may affect the cumulative evidence (e.g., } \\
\text { publication bias, selective reporting within studies). }\end{array}$ & 5 \\
\hline Additional analyses & 16 & $\begin{array}{l}\text { Describe methods of additional analyses (e.g., sensitivity or subgroup analyses, meta- } \\
\text { regression), if done, indicating which were pre-specified. }\end{array}$ & Not applicable \\
\hline
\end{tabular}

RESULTS

\begin{tabular}{lrllll}
\hline Study selection & 17 & $\begin{array}{l}\text { Give numbers of studies screened, assessed for eligibility, and included in the review, } \\
\text { with reasons for exclusions at each stage, ideally with a flow diagram. }\end{array}$ & 6 \\
\hline Study characteristics & 18 & $\begin{array}{l}\text { For each study, present characteristics for which data were extracted (e.g., study size, } \\
\text { PICOS, follow-up period) and provide the citations. }\end{array}$ & Table 1 \\
\hline Risk of bias within studies & 19 & $\begin{array}{l}\text { Present data on risk of bias of each study and, if available, any outcome level assessment } \\
\text { (see item 12). }\end{array}$ & Table 1 \\
\hline
\end{tabular}




\begin{tabular}{|c|c|c|c|}
\hline Section/topic & $\#$ & Checklist item & Reported on page \# \\
\hline $\begin{array}{l}\text { Results of individual } \\
\text { studies }\end{array}$ & 20 & $\begin{array}{l}\text { For all outcomes considered (benefits or harms), present, for each study: (a) simple } \\
\text { summary data for each intervention group (b) effect estimates and confidence } \\
\text { intervals, ideally with a forest plot. }\end{array}$ & Fig. 2 \\
\hline Synthesis of results & 21 & $\begin{array}{l}\text { Present results of each meta-analysis done, including confidence intervals and } \\
\text { measures of consistency. }\end{array}$ & 6 \\
\hline Risk of bias across studies & 22 & Present results of any assessment of risk of bias across studies (see Item 15). & 6 \\
\hline Additional analysis & 23 & $\begin{array}{l}\text { Give results of additional analyses, if done (e.g., sensitivity or subgroup analyses, meta- } \\
\text { regression [see Item 16]). }\end{array}$ & Not applicable \\
\hline
\end{tabular}

DISCUSSION

\begin{tabular}{lrl}
\hline Summary of evidence & 24 & $\begin{array}{l}\text { Summarize the main findings including the strength of evidence for each main } \\
\text { outcome; consider their relevance to key groups (e.g., healthcare providers, users, and } \\
\text { policy makers). }\end{array}$ \\
\hline Limitations & 25 & $\begin{array}{l}\text { Discuss limitations at study and outcome level (e.g., risk of bias), and at review-level } \\
\text { (e.g., incomplete retrieval of identified research, reporting bias). }\end{array}$ \\
Conclusions & 26 & $\begin{array}{l}\text { Provide a general interpretation of the results in the context of other evidence, and } \\
\text { implications for future research. }\end{array}$ \\
\hline
\end{tabular}

FUNDING

\begin{tabular}{llll}
\hline Funding & 27 & $\begin{array}{l}\text { Describe sources of funding for the systematic review and other support (e.g., supply of } \\
\text { data); role of funders for the systematic review. }\end{array}$ & 9 \\
\hline
\end{tabular}

From: Moher D, Liberati A, Tetzlaff J, Altman DG, The PRISMA Group. Preferred Reporting Items for Systematic Reviews and Meta-Analyses: The PRISMA Statement. PLoS Med 2009;6:e1000097. 